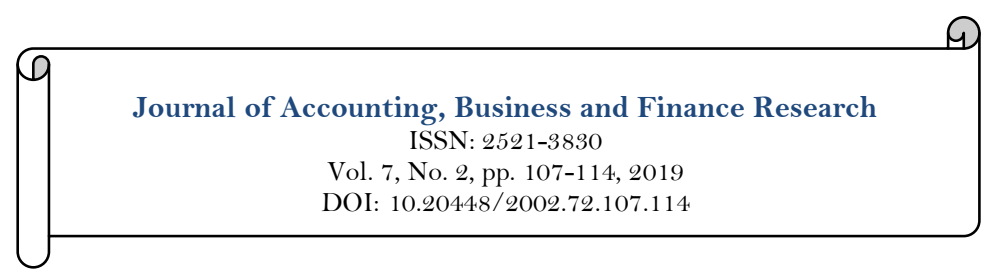

check for
updates

\title{
Determinants of Environmental Disclosure. Does Leverage Matter? Reflection from Firms Listed in the Nairobi Security Exchange
}

\author{
Tarus John Kipngetich ${ }^{\mathbf{*}}$ \\ Joel Tenai ${ }^{2}$ \\ Ronald Bonuke ${ }^{3}$ \\ ${ }^{1,2}$ Department of Accounting and Finance, Moi University, Kenya. \\ ${ }^{2}$ Email:jktarus47@gmail.com \\ ${ }^{s}$ Department of Marketing and Logistics, Moi University, Kenya.
}

\begin{tabular}{|c|c|}
\hline Abstract & \\
\hline $\begin{array}{l}\text { This paper aimed to examine the effect of leverage on environmental accounting } \\
\text { disclosure among the firms listed in the Nairobi Securities Exchange, Kenya. } \\
\text { The research was guided by the stakeholder's theory. The study adopted both } \\
\text { explanatory and longitudinal research designs. The target population comprised } \\
\text { of the } 65 \text { listed firms at Nairobi Securities Exchange from } 2008 \text { to } 2017 \text {. } \\
\text { However, inclusion criteria were the } 27 \text { listed firms consistently operating from } \\
2008 \text { to } 2017 \text { giving a total of } 270 \text { firm-year observations. The findings } \\
\text { showed that leverage }(\beta=-.16, \rho<.05) \text { had a negative and significant effect on } \\
\text { environmental disclosure in Kenyan listed firms. Similarly, the overall } R^{2} \\
\text { showed a joint contribution of } 17 \% \text { of predictor variables that explain } \\
\text { environmental accounting disclosure. The study concludes that leverage is a key } \\
\text { predictor of environmental accounting disclosure. Firms listed at the Nairobi } \\
\text { Securities Exchange ought to reduce debt financing so as to increase the level of } \\
\text { environmental accounting disclosure. }\end{array}$ & $\begin{array}{l}\text { Keywords: } \\
\text { Leverage } \\
\text { Environmental accounting } \\
\text { disclosure } \\
\text { Stakeholders theory } \\
\text { Board size } \\
\text { Firm size. } \\
\text { JEL Classification: } \\
\text { F18, L2. } \\
\text { Licensed: } \\
\text { This work is licensed under a } \\
\text { Creative Commons Attribution } 4.0 \\
\text { License. } \\
\text { Publisher: } \\
\text { Scientific Publishing Institute } \\
\text { Accepted: } 17 \text { October } 2019 \\
\text { Published: } 1 \text { November } 2019\end{array}$ \\
\hline
\end{tabular}

Funding: This study received no specific financial support.

Competing Interests: The authors declare that they have no competing interests.

\section{Introduction}

Over the previous few years, the demand for corporations to be socially accountable and environmentally sensitive has increased. Perhaps stakeholder's consistent and increasing requirements have resulted in businesses investing strongly in environmental expenses (Jeroh \& Okoro, 2016). To begin with, environmental issues previously were given less attention and minimal significance due to the absence of economic value, this can no longer be maintained since the issue has attracted domestic and international attention. The main strategy for assessing the environmental footprint of a company is to examine whether they are involved in environmental disclosure (Jeroh \& Okoro, 2016). The new corporate reporting order presently needs businesses to incorporate environmental responsibility into their reporting of profitability. This awareness has resulted in an enhanced understanding of corporate social responsibility, measuring an organization's achievement not only in terms of its economic results but also in terms of its social and environmental impact. According to Dissanayake, Tilt, and Lobo (2017) information on environmental accounting may be financial or non-monetary, but accountants are trying to transform qualitative environmental information into quantitative information. 
According to Masud, Kaium, and Hossain (2016) argued that positive or negative environmental disclosure indicates whether the organization is environmentally friendly or harmful. In addition, nonfinancial data on financial, social and environmental results promotes the knowledge of leadership obligations by stakeholders (D'Amico, Di Vita, Chinnici, Pappalardo, \& Pecorino, 2014). According to Behram (2015) corporations reveal environmental information in their annual report to increase their visibility and send specific signals and messages indicating that companies are conscious of environmental problems. Furthermore, companies may gain from offering the public with more information by reducing their capital costs and increasing their shareholder's pure money flows, thereby improving their values (Omaima \& Claire, 2010).

According to Bassey, Sunday, and Okon (2013) environmental accounting is intended to provide information for assessing the conduct of a company towards its surroundings and the financial impact of such actions. The environmental accounting system, therefore, offers economic data in monetary units as well as non-financial data in physical units (Panigrahi, Zainuddin, \& Azizan, 2015). Irish (2000) argued that environmental accounting covers all information relating to the environment including environment-related expenditure, environmental benefits of products and details regarding sustainable operations. In addition, Yakhou and Dorweiler (2004) argued that environmental accounting covers the whole accounting field. Therefore, the reports generated by environment accounting serve both the internal and external users of information. Furthermore, the information also enables managers to make pricing choices, control overheads, and budgeting for capital. It offers the public and the economic community with data that is of interest (Beredugo \& Mefor, 2012).

In modern times the connection between company organizations and their environment faced dramatic changes. Until recently, environmental and social issues were not treated seriously in management goals because they were not considered to have any important economic effect. But in an effort to obtain credibility, however, most organizations acknowledged the significance of their environment to their companies and the need to protect it Pereira Eugénio, Costa Lourenço, and Morais (2013). According to Díez-Martín, PradoRoman, and Blanco-González (2013) asserted that a number of corporations failed not because they lack funds or because of defective products, but due to complete loss of their legitimacy or deterioration.

Environmental accounting and reporting improve decision-making quality. It allows businesses to set objectives to reduce major environmental indicators such as greenhouse emissions, gas emissions, power use, resource use. In addition, through environmental accounting and reporting, corporations understand the need to change unsustainable consumption, unfavorable patterns of production, thereby protecting and managing natural resources accessible (Beredugo \& Mefor, 2012). Therefore, accounting information is necessary for accountability, comparability, and probity. Nonetheless, the lack of such information could be equal to prejudice, non-transparency, fraud, and risk-taking. The situation could dissuade sponsorships from customers, vendors, investors, surrounding communities and possible public sanctions that are becoming aware of the contribution of an organization to sustainable development (Beredugo \& Mefor, 2012). Thus, it is extremely important to determine the effect of leverage on environment accounting disclosure.

\section{Theoretical Framework}

The study was anchored on stakeholder theory. In the context of these developments, the concept of stakeholders first emerged as a defense of the company's social obligations and a statement that executives must have moral obligations towards other stakeholders, not just their shareholders (Hendry, 2001). These interested parties are the stakeholders with a stake in the company and they are a critical factor in determining the success or failure of the company. According to stakeholder theory, the organization involves a range of stakeholders and each of them deserves some return for their participation (Crowther \& Jatana, 2005). Furthermore, Freeman (1984) made a major attempt to lay the framework for stakeholder theory growth in the early 1980s. The theory of stakeholders presumed that values are a needed component of company activities and reject the separation of ethics and economics.

The stakeholder theory's policy view treats all the company's stakeholders equally and does not take into consideration each stakeholder's authority (Deegans \& Unerman, 2006; Waris \& Muhammed, 2013). In addition, the normative stakeholder theory urges the executives to work for the benefits of all the stakeholders (Deegan \& Jeffry, 2006). Furthermore, with regards to the managerial perspective of stakeholder theory is concerned, it takes into account the interests of a limited number of interested parties, who have significant power to influence the organization. The power of the company relies on the nature of assets or resources held by the stakeholders (Waris \& Muhammed, 2013). Moreover, the theory promotes the concept that the conduct of different stakeholder parties promotes management to match business requirements with their environment. The stakeholder theory management branch offers a structure for analyzing CSED in an organization-centric manner. The achievement of handling stakeholders properly by discharging CSED accountability is probably some type of organizational legitimacy (Van Der Laan, 2010). According to stakeholder theory, the economic performance of a firm also has a beneficial impact on voluntary environmental and social disclosure (Cho \& Patten, 2007; Cormier \& Magnan, 2003; Ho \& Taylor, 2007) and on investment in social responsibility. 


\section{Hypothesis Development}

According to stakeholder theory, the higher the financial leverage is, the higher the debt to equity ratio is, the greater the conflict of interest between the parties involved, such as debtors, shareholders, and managers. In addition, the demand for providing information to satisfy the stakeholders are also higher. However, companies with greater debt ratios often face financial difficulties and solvency, so it is very hard for them to decide on environmental and social expenditure according to cost and benefit theory. Furthermore, empirical literature showed that the debt-to-equity ratio is reversed to the level of disclosure (Chiu \& Wang, 2014)

According to Branco and Rodrigues (2008) disclosure of corporate social responsibility and leverage has been discovered to have no connection. However, (Christopher \& Filipovic, 2008; Ma \& Zhao, 2009) indicated that the higher the leverage the more the company is likely to disclose social issues. In addition, it is asserted that extremely leveraged firms have fewer environmental problems to report because these firms are more likely to comply with environmental regulations (Wu, Jia - Liu, Linxiao. - Sulkowski, \& Adam, 2010). Therefore, it's anticipated that the higher the financial leverage, the less likely the company would reveal social and environmental accounting.

Leverage has been suggested to explain differences in the extent of corporate economic disclosure (Demir \& Bahadir, 2014). The agency theory is used in disclosure literature to clarify the motivation to provide more disclosure to executives of high-leverage corporations (Morris, 1987). In addition, Alsaeed (2006) asserted that companies with relatively greater debt concentrations in their capital structure are susceptible to greater agency costs. Managers, therefore, have an incentive to lessen the expenses of agency costs through disclosure or reveal more accounting information to meet the debenture holder's requirements (Morris, 1987). Furthermore, extremely leveraged corporations guarantee creditors that they are less likely to bypass their covenant claims by disclosing more data (Ali, Ahmed, \& Henry, 2004).

According to legitimacy theory on leverage attribute, indicates that corporations may use public disclosure to convey information to stakeholders especially those pertaining to environmental impacts (Magness, 2006). Further, leverage is described as the ratio of debt to equity, it demonstrates the choice of executives on an optimal combination of funding alternatives. Moreover, because of their fixed interest capital, firms with greater leverage are generally considered to be riskier. Thus high leverage firms that fail to demonstrate that they are environmentally sensitive are likely to be threatened with their survival. Studies by Jensen (1986) for instance believed that high levered companies tend not to have incentives to invest suboptimally in order to maximize wealth and this perhaps might render them environmentally insensitive.

Many studies indicate that leverage is a key commonly employed firm's attribute for corporate environmental disclosure (Ahmad, Salleh, \& Junaini, 2003; Bouten, Everaert, Liedekerke, Moor, \& Christiane's, 2012; Cormier \& Magnan, 2003; Haniffa \& Cooke, 2015). In addition, from legitimacy theory perspective studies such as (Ahmad et al., 2003; Maliah, Norhayati, \& Fatima, 2014; Naser, Alhussaini, Alkwari, \& Nuseibeh, 2016; Roberts, 1992) have demonstrated a positive connection between environmental disclosure and leverage. Nonetheless, other studies such as (Brammer, Brooks, \& Pavelin, 2006; Mejda \& Hakim, 2013; Toluwa, Okun, \& Ikhenade, 2016) reported a negative association. However, given the inconsistent empirical findings, this study re-examined the association between leverage and environmental accounting disclosure.

Environmental reporting is affected by the capital structure in a two-fold manner. First, environmental disclosure tells creditors about how the company uses extra-contractually employed resources, such as the environment, in the manufacturing phase of the company, which is funded by the combination of debt and equity capital.

On the other side, excessively leveraged companies may not have the necessary resources available for mainly discretionary communication methods with stakeholders, such as environmental reporting. In addition, the empirical proof in the literature has also recorded the adverse impact of financial leverage on the extent of CSR and environmental reporting (Makori \& Jagongo, 2013). Mohamed, Olfa, and Faouzi (2014) discovered that firms with better results of environmental disclosure indicate cheaper equity funding in their research on Tunisian firms.

The research revealed that investment in practices of corporate environmental disclosure helps to reduce equity costs for companies. Similarly, Cormier and Gordon (2001) indicate that disclosure of environmental information may boost ownership expenses for extremely leveraged companies and that such costs may make loan negotiations more hard and expensive. Moreover, according to (Wu et al., 2010) asserted that extremely leveraged firms have fewer environmental problems to report because these firms are more likely to comply with environmental regulations. For these reasons, it is also possible to expect an adverse connection between financial leverage and environmental disclosure quantity. Empirical studies such as (Ahmad et al., 2003; Brammer et al., 2006; Eng \& Mak, 2003; Ho \& Taylor, 2007; Wu et al., 2010) have also recorded this adverse connection. Therefore, based on the above link between leverage and environmental accounting disclosure and with little and inconclusive findings, this study hypothesized that:

$H_{l:}$ Firms with high leverage have a high probability of disclosure of environmental accounting information. 


\section{Research Methodology}

The research sought to describe and explore the perceived reality of environmental disclosure and leverage quantitatively. This approach to positivism has been implemented in this research. Positivism is often linked with quantitative, scientific, traditionalist and objective research especially when the data is predetermined and highly structured which is related to the understanding of this research (Gioia \& Pitre, 1990). In addition, this study adopted the longitudinal study which comprised 27 listed firms from the Manufacturing, Agriculture sector, Constructions \& Allied, Energy \& Petroleum and Automobiles and Accessories listed in Nairobi stock exchange. Furthermore, the period of the empirical analysis was ten years for firms that have consistently operated from 2008 to 2017 giving 270 observations. The study collected secondary data using content analysis from the audited annual financial reports which were sourced from capital market authority or downloaded from http://www.cmarcp.or.ke/index.php/financial-reports-accounts, company website, and http://africanfinancials.com.

\section{Measurement of Variables}

The study used an environmental disclosure index to measure environmental accounting disclosure. In addition, the environmental disclosure score (EDS) was calculated by assigning dummy scores based on data being available. Firms who disclose information on a particular item were assigned a value of 1 or otherwise 0 . Similarly, the value of each company's (EDS) was calculated as the proportion of complete disclosure results to the highest possible results (complete amount of items included in the index) as shown in Table 1.

\begin{tabular}{l|l|l}
\hline $\begin{array}{l}\text { Measurements } \\
\text { variable name }\end{array}$ & Measurement of variables & Author(s) \\
\hline Dependent variable & $\begin{array}{l}\text { Environmental accounting disclosures was } \\
\text { measured by Environmental Disclosure } \\
\text { Index (EDI) adopted from the Global } \\
\text { Reporting Initiative (GRI 2008). }\end{array}$ & Ezhilarasi and Kabra (2017) \\
\hline $\begin{array}{l}\text { Environmental } \\
\text { accounting disclosure }\end{array}$ & Ratio of debt to equity. & Rafique (2010) \\
\hline Independent variables & $\begin{array}{l}\text { Determined by taking the number of } \\
\text { directors sitting on the board. }\end{array}$ & $\begin{array}{l}\text { (Jehn \& Bezrukova, 2004; } \\
\text { Roberson \& Park, 2007) }\end{array}$ \\
\hline Leverage & Measured as the log of total asset. & Henry (2010) \\
\hline Board size
\end{tabular}

\section{Model Specification}

The study employed the hierarchical multiple regression model (Baron \& Kenny, 1986). The hypothesis was tested first using the random-effects model, fixed-effect model, and thereafter a Hausman test was carried out to establish which of the two models was the best fit in predicting the change in environmental accounting disclosure among selected listed firms in Nairobi Securities Exchange as specified in the equation below:

\section{$E A D_{\text {it }}=\beta_{\text {oit }}+\mathrm{C}+\beta_{1 \mathrm{it}} \mathrm{LV}_{4 \mathrm{it}}+\varepsilon$ \\ Where:}

$\boldsymbol{E} \boldsymbol{A D}$; Environmental accounting disclosure.

$\boldsymbol{\alpha}$; Constant term or intercept.

$\boldsymbol{\beta}_{\mathbf{0}}$ and $\boldsymbol{\beta}_{\mathbf{1}}$; Beta coefficients.

C; Control Variables (Board and firm size).

$\boldsymbol{L} \boldsymbol{V} ;$ Leverage.

$\boldsymbol{B} \boldsymbol{E} \boldsymbol{D} ;$ Board education diversity.

$\boldsymbol{\varepsilon}$; Random error term.

\section{Results}

The company's descriptive statistics provide a summary of research variables statistics. Table 2 presents descriptive statistics and correlation results on the dependent and independent variables. In addition, using a scoring framework to create an EDI, consistent with prior research findings, the results show that the mean value of disclosure of environmental accounting ranged from a minimum of 0.06 to a maximum of 0.87. The average value for environmental accounting disclosure was 0. 53. Although the level of environmental accounting reported during the period 2008 to 2017 is low on an aggregate basis, the extent of environmental disclosure has increased between 2008 and 2017 as well as the number of Kenyan companies disclosing environmental information. Indeed, despite the low average value of the 
environmental disclosure index, it has positively evolved, both overall and in each industry. It can, therefore, be claimed that the environmental reporting practices of the Kenyan companies have improved over the period of time studied, although their level of environmental disclosure is still below those of other developed nations, such as Spain.

Leverage was at a mean of 1.62 with a minimum of 0.0 and a maximum of 23.09 on average. The board had a minimum of 2 members and a maximum of 19 . While, on average, the board is composed of 9 members $($ mean $=9.42)$. Furthermore, the firm size was at a mean of 9.68 with a minimum of 8.25 and a maximum of 11.28. The findings also revealed that leverage had a negative and significant correlation with environmental accounting disclosure $(r=-0.184)$. However, board size and firm size did not have a significant correlation with environmental accounting disclosure.

Table-2. Descriptive and correlation results.

\begin{tabular}{|c|c|c|c|c|c|c|c|c|c|}
\hline Obs $=270$ & Min & Max & Mean & Sd & Skew & EAD & Lev & BS & Fs \\
\hline EAD & 0.06 & 0.87 & 0.53 & 0.22 & -0.69 & 1 & & & \\
\hline Lev & 0.00 & 23.09 & 1.06 & 2.39 & 5.53 & $-.184 * *$ & 1 & & \\
\hline $\mathrm{BS}$ & 2.00 & 19.00 & 9.42 & 3.64 & -0.23 & -0.072 & $-.124 *$ & 1 & \\
\hline $\mathrm{FS}$ & 8.25 & 11.28 & 9.68 & 0.60 & 0.14 & -0.039 & 0.074 & -0.028 & 1 \\
\hline
\end{tabular}

\section{Testing of Hypothesis}

The research first tested the hypotheses using the random effect model. The appropriate outcomes to be noted from Table 3 are the p-values and the regressor's coefficient. The significance level is set at 95\% levels, with p-values greater than 0.05 considered to be insignificant. The random model showed that a $19 \%$ variation in environmental accounting disclosure was explained by leverage, the board size, and company size. The Wald $\chi^{2}$ test is used to check whether the response variable, environmental accounting disclosure is dependent on the model. in addition, if the p-value related to the Wald $\chi^{2}$ is $<0.05$ then the response variable significantly depends on the model. From the findings, Wald $\chi^{2}(3)=64.92$, p-value $=0.00$ indicating that environmental accounting disclosure depends on the model showing that the change in EAD dependent on the effects of the explanatory variables. Furthermore, the projected standard deviation of $\alpha \mathrm{i}$ (sigma_u) is 0.10 which is small than the standard deviation of cit (sigma_e) which is 0.66 indicating that the errors of the individual elements are less essential than the idiosyncratic error. The standard error component model assumes that the regression disturbances are homoscedastic.

In addition, the study used the model of fixed effect to test the hypothesis. The fixed-effect model, according to Bickel (2007) comprised of distinctive characteristics that do not differ over time. From Table 3, the model showed that a $17 \%$ variation in environmental accounting disclosure was explained by leverage, the board size, and company size. Furthermore, based on the results of the Hausman test, the fixed-effect model was used as the best fit model in the final analysis to overcome the deficiencies associated with the results of the fixed effect (Wachira, 2017). Similarly, the R-square of 0.17 reveals a quite strong strength of the relationship between the model and the variables, that approximately $17 \%$ of the variation in the output can be explained by the independent variables in the model. Further, this relationship is statistically significant as the $\mathrm{F}$ value $(\mathrm{F}$ value $=23, \mathrm{p}<0.0)$ of the model is significant at the 0.01 level.

Findings from Table 3 showed that the hypothesis failed to be rejected $(\beta-.16, p=0.02<.05)$. This indicates that high-leverage corporations in Kenyan are likely to lower their level of environmental disclosure. The finding support (Mejda \& Hakim, 2013) the opinion that there is a negative connection between company leverage and environmental disclosure determinants. The study findings contrary to that of Cormier and Magnan (2003) revealed that leverage did not significantly influence the level of disclosures. Similarly, Ahmad et al. (2003) found that environmental disclosure is high for firms with a low rate of financial leverage. The higher the leverage, the riskier the company will be as interest and principal payments are obligations that are fixed. These are to be paid irrespective of the level of operating profits. Furthermore, if these obligations are not fulfilled, this may result in bankruptcy and may result in the transfer of ownership of the property of the companies from shareholders to bondholders (Ross, Westerfield, \& Jaffe, 1996). From a legitimacy theory view, it can be concluded that these firms can openly reveal more quality environmental information in order to legitimize their company as well as making such firms appear less risky. Many studies, however, demonstrate a non-statistically significant association between financial leverage and the magnitude of environmental disclosures (Alsaeed, 2006; Grigoris, 2014; Ho \& Taylor, 2007).

Similarly, Chiu and Wang (2014) demonstrated a reversal of the debt-to-equity ratio to the disclosure level. Furthermore, the findings are not consistent with that of (Christopher \& Filipovic, 2008; Ma \& Zhao, 2009) which showed that the greater the leverage, the more likely the business is to reveal social and environmental information. Previous studies have also shown that the magnitude of environmental reporting is negatively affected by financial leverage (Andrikopoulos \& Kriklani, 2013; Brammer et al., 2006). Furthermore, it is also suggested that firms with greater leverage are more likely to increase the quantity of 
corporate disclosure in order to decrease agency expenses. Ho and Taylor (2007). For these reasons, it is possible to expect a favorable connection between leverage and environmental disclosure, and this argument is backed by the outcomes of empirical research such as (Clarkson, Li, Richardson, \& Vasvari, 2008; Huang \& Kung, 2010; Meng, Zeng, \& Tam, 2013).

\begin{tabular}{|c|c|c|}
\hline Variable & Random effect & Fixed effect \\
\hline EAD & Coef.(se) & Coef.(se) \\
\hline LEVE & $\left(-0.15(.02)^{* *}\right.$ & $\left(-0.16(.02)^{* *}\right.$ \\
\hline BS & $(-0.14(.10)$ & $0.03(.14)$ \\
\hline $\mathrm{FS}$ & $0.40(1.00)$ & $(-0.02(.1 .00)$ \\
\hline _cons & $(-1.22(.160)$ & $(-0.63(2.11)$ \\
\hline sigma_u & 0.10 & 0.28 \\
\hline sigma_e & 0.66 & 0.66 \\
\hline Rho & 0.02 & 0.16 \\
\hline Overall & 0.19 & 0.17 \\
\hline Wald chi2(3) & 64.92 & \\
\hline Prob $>$ chi 2 & 0.00 & \\
\hline $\mathrm{F}(3,234)$ & & 23.00 \\
\hline Prob $>F$ & & 0.00 \\
\hline \multicolumn{3}{|c|}{\begin{tabular}{c|l} 
Hausman & \\
\end{tabular}} \\
\hline \multicolumn{3}{|c|}{$\operatorname{chi} 2(3)=(\mathrm{b}-\mathrm{B})^{\prime}\left[\left(\mathrm{V} \_\mathrm{b}-\mathrm{V} \_\mathrm{B}\right)^{\wedge}(-1)\right](\mathrm{b}-\mathrm{B})$} \\
\hline \multicolumn{3}{|c|}{$=\quad 12.37$} \\
\hline Prob $>$ chi $2=$ & & \\
\hline
\end{tabular}

\section{Conclusion and Recommendations}

Findings showed that leverage reduces the environmental accounting disclosure. The study finds that companies with high financial leverage reduce the volume of corporate social disclosure while companies with relatively lower financial leverage have sufficient funds for financing corporate social disclosure. Therefore, the study recommends that firms should engage in voluntary corporate social disclosure no matter the level of their financial leverage. Consequently, this research calls for a more proactive effort from policymakers and other standard-setting organizations on the need to introduce a standard framework for the mandatory disclosure of corporate environmental information. This effort will yield to a great extent a higher level of environmental disclosure as well as bringing about standardization in the environmental disclosure design. This will eventually enhance comparability and make it easier for investors to determine which companies are more socially responsible. In order for firms to sustain themselves in a global market over a long period of time, they should disclose environmental information irrespective of their multinational or domestic status, leverage or earning capacity.

The study offers a significant contribution to academic research and practice. While, it is recommended that further studies should evaluate the influence of other firm's attributes (Macro factors such as inflation, interest rates, and GDP) on environmental accounting disclosure. Lastly, future research can be extended to incorporate other sectors of the economy.

\section{References}

Ahmad, Z., Salleh, H., \& Junaini. (2003). Determinants of environmental reporting in Malaysia. International Journal of Business Studies, 2(1), 69-90.

Ali, M. J., Ahmed, K., \& Henry, D. (2004). Disclosure compliance with national accounting standards by listed companies in South Asia. Accounting and Business Research, 34(3), 183 - 199. Available at: https://doi.org/10.1080/00014788.2004.9729963.

Alsaeed, K. (2006). The association between firm-specific characteristics and disclosure the case of Saudi Arabia. Managerial Auditing Journal, 21, 476-496. Available at: https://doi.org/10.1 108/02686900610667256.

Andrikopoulos, A., \& Kriklani, N. (2013). Environmental disclosure and financial characteristics of the firm: The case of Denmark. Corporate Social Responsibility and Environmental Management, 20(1), 55-64. Available at: https://doi.org/10.1002/csr.1281.

Baron, R. M., \& Kenny, D. A. (1986). The moderator-mediator variable distinction in social psychological research: Conceptual, strategic, and statistical considerations. Journal of Personality and Social Psychology, 51(6), 1173-1 182. Available at: https://doi.org/10.1037//0022-3514.51.6.1173.

Bassey, E. B., Sunday, O. E., \& Okon, E. E. (2013). The impact of environmental accounting and reporting on organizational performance of selected oil and gas companies in the Niger Delta Region of Nigeria. Research Journal of Finance and Accounting, 4(3), 57-73.

Behram, N. (2015). A cross-sectoral analysis of environmental disclosures in a legitimacy theory context. Journal of Management and Sustainability, 5(1), $20-37$. 
Beredugo, S., \& Mefor, I. (2012). The impact of environmental accounting and reporting on sustainable development in Nigeria. Research Journal of Finance and Accounting, 3(7), 55-63.

Bickel, R. (2007). Multilevel analysis for applied research: It's just regression: Guilford Press.

Bouten, L., Everaert, P., Liedekerke, L. V., Moor, L. D., \& Christiane’s, J. (2012). Corporate social responsibility reporting: A comprehensive picture. Accounting Forum, 35(3), 187-204.

Brammer, S., Brooks, C., \& Pavelin, S. (2006). Corporate social performance and stock returns: UK evidence from disaggregate measures. Financial Management, 35(3), 97-116. Available at: https://doi.org/10.1111/j.1755053x.2006.tbo0 149.x.

Branco, M. C., \& Rodrigues, L. L. (2008). Corporate social responsibility and resource-based perspectives. Journal of Business Ethics, 69(2), 111-132.

Chiu, T. K., \& Wang, Y. H. (2014). Determinants of social disclosure quality in Taiwan: An application of stakeholder theory. Journal of Business Ethics, 129(2), 379-398.

Cho, C. H., \& Patten, D. M. (2007). The role of environmental disclosures as tools of legitimacy: A research note. Accounting, Organizations and Society, 32(7/8), 639-647.

Christopher, T., \& Filipovic, M. (2008). The extent and determinants of disclosure of global reporting initiative guidelines: Australian evidence. The Journal of Contemporary Issue in Business and Government, 14(2), 17-40.

Clarkson, P. M., Li, Y., Richardson, G. D., \& Vasvari, F. P. (2008). Revisiting the relation between environmental performance and environmental disclosure: An empirical analysis. Accounting, Organizations and Society, 33(4/5), 303-327. Available at: https://doi.org/10.1016/j.aos.2007.05.003.

Cormier, D., \& Gordon, I. M. (2001). An examination of social and environmental reporting strategies. Accounting, Auditing E Accountability Journal, 14(5), 587-617. Available at: https://doi.org/10.1108/eum0000000006264.

Cormier, D., \& Magnan, M. (2003). Environmental reporting management: A continental European perspective. Journal of Accounting and Public Policy, 22(1), 43-62. Available at: https://doi.org/10.1016/s0278-4254(02)00085-6.

Crowther, D., \& Jatana, R. (2005). International dimensions of corporate social responsibility: ICFAI University Press.

D'Amico, M., Di Vita, G., Chinnici, G., Pappalardo, G., \& Pecorino, B. (2014). Short food supply chain and locally produced wines: Factors affecting consumer behavior. Italian Journal of Food Science, 26(3), 329-334.

Deegan, C., \& Jeffry, U. (2006). Financial accounting theory. McGraw-Hill Education: Berkshire SL6 2QL.

Deegans, C., \& Unerman. (2006). Corporate legitimacy and environmental reporting - Deegan and underman contentions. Accounting Research Blog, from https://richardcollinsaccountingblog.wordpress.com/2012/04/28/corporate-legitimacy-and-environmentalreporting-deegan-and-unermans-2006-contentions-3/.

Demir, V., \& Bahadir, O. (2014). An investigation of compliance with international financial reporting standards by listed companies in Turkey. Accounting and Management Information Systems, 13(1), 4-34.

Díez-Martín, F., Prado-Roman, C., \& Blanco-González, A. (2013). Beyond legitimacy: Legitimacy types and organizational success. Management Decision, 51(10), 1954-1969. Available at: https://doi.org/10.1108/md-08-2012-0561.

Dissanayake, D., Tilt, C., \& Lobo, M. X. (2017). Sustainability reporting by listed companies in Sri Lanka. Journal of Cleaner Production(30), 1-14

Eng, L. L., \& Mak, Y. T. (2003). Corporate governance and voluntary disclosure. Journal of Accounting and Public Policy, $22(4), 325-345$.

Ezhilarasi, G., \& Kabra, K. C. (2017). Factors influencing environmental disclosures: Evidence from India. IUP Journal of Accounting Research \& Audit Practices, 16(1), 7-24.

Freeman, R. E. (1984). Strategic management: A stakeholder approach. Boston: Pitman.

Gioia, D. A., \& Pitre, E. (1990). Multiparadigm perspectives on theory building. Academy of Management Review, 15(4), 584602. Available at: https://doi.org/10.2307/258683.

Grigoris. (2014). Corporate governance and financial characteristic effects on the extent of corporate social responsibility disclosure. Social Responsibility Journal, 10, 569-590. Available at: 10.1 108/SRJ-02-2013-0008.

Haniffa, R. M., \& Cooke, T. E. (2015). Culture, corporate governance, and disclosure in Malaysian corporations. ABACUS, $38(3), 317-349$.

Hendry, J. (2001). Missing the target: Normative stakeholder theory and the corporate governance debate. Business Ethics Quarterly, 11(1), 159-176.

Henry, D. (2010). Agency costs, ownership structure and corporate governance compliance: A private contracting perspective. Pacific-Basin Finance Journal, 18(1), 24-46.

Ho, L.-C. J., \& Taylor, E. M. (2007). An empirical analysis of triple bottom-line reporting and its determinants: Evidence from the United States and Japan. Journal of International Financial Management \& Accounting, 18(2), 123-150. Available at: https://doi.org/10.1111/j.1467-646x.2007.01010.x.

Huang, C. L., \& Kung, F. H. (2010). Drivers of environmental disclosure and stakeholder expectation: Evidence from Taiwan. Journal of Business Ethics, 96(3), 435-451. Available at: https://doi.org/10.1007/s 10551-010-0476-3.

Irish, T. (2000). Environmental Accounting and Social Responsibility and its impact on Annual Report (7th ed., pp. 1-2): Business Article.

Jehn, K. A., \& Bezrukova, K. (2004). A field study of group diversity, workgroup context, and performance. Journal of Organizational Behavior, 25, 703-729. Available at: https://doi.org/10.1002/job.257.

Jensen, M. C. (1986). Agency cost of free cash flow, corporate finance, and takeovers. American Economic Review, 76(2), 323329.

Jeroh, E., \& Okoro, G. E. (2016). Effect of environmental and dismantling costs on firm performance among selected oil and gas companies in Nigeria. Sahel Analyst: Journal of Management Sciences, 14(5), 14-26.

Ma, L. F., \& Zhao, Y. (2009). Corporate social disclosure and determinates analysis in listed companies in China. Security Market Guide, 3, 3-9. 
Magness, V. (2006). Strategic posture, financial performance, and environmental disclosure: An empirical test of legitimacy theory. Accounting, Auditing and Accountability Journal, 19(4), 540-563. Available at: http://dx.doi.org/10.1108/09513570610679128.

Makori, D. M., \& Jagongo, A. (2013). Environmental accounting and firm profitability: An empirical analysis of selected firms listed in Bombay stock exchange, India. International Journal of Humanities and Social Science, 3(18), 248-256.

Maliah, S., Norhayati, A., \& Fatima, A. H. (2014). Determinants of environmental reporting quality in Malaysia. International Journal of Economics, Management and Accounting, 22(1), 63-90.

Masud, M., Kaium, A., \& Hossain, M. (2016). Environmental accounting concept and reporting practice: Evidence from the banking sector of Bangladesh. Mohammad, Environmental Accounting Concept and Reporting Practice: Evidence from Banking Sector of Bangladesh (January 20, 2016).

Mejda, M. A., \& Hakim, B. O. (2013). A study of the determinants of corporate environmental disclosure in MENA emerging markets. Journal of Review on Global Economics, 2, 48-59.

Meng, X. H., Zeng, S. X., \& Tam, C. M. (2013). From voluntarism to regulation: A study on ownership, economic performance, and corporate environmental information disclosure in China. Journal of Business Ethics, 116(1), 217232.

Mohamed, T., Olfa, B. J., \& Faouzi, J. (2014). Corporate social disclosure: Explanatory theories and conceptual framework. International Journal of Academic Research in Management, 3(2), 208-225.

Morris, R. D. (1987). Signaling, agency theory and accounting policy choice. Accounting and Business Research, 18(69), 47-56. Available at: https://doi.org/10.1080/00014788.1987.9729347.

Naser, K., Alhussaini, A., Alkwari, D., \& Nuseibeh, R. (2016). Determinants of corporate social disclosure in developing countries: The case of Qatar. Advances in International Accounting, 19, 1-23. Available at: 10.1016/So897$3660(06) 19001-7$.

Omaima, H., \& Claire, M. (2010). Disclosure measurement in the empirical accounting literature: A review article (pp. 158). Economic and Working Paper Series No $10-18$

Panigrahi, S. K., Zainuddin, Y., \& Azizan, A. (2015). Comparing traditional and economic performance measures for creating shareholder's value: A perspective from Malaysia. International Journal of Academic Research in Accounting, Finance, and Management Sciences, 4(4), 280-289.

Pereira Eugénio, T., Costa Lourenço, I., \& Morais, A. I. (2013). Sustainability strategies of the company TimorL: Extending the applicability of legitimacy theory. Management of Environmental Quality: An International Journal, 24(5), 570-582. Available at: https://doi.org/10.1108/meq-03-2011-0017.

Rafique, M. (2010). Effect of profitability \& financial leverage on capital structure: A case of Pakistan's automobile industry. Economics and Finance Review, 1(4), 50-58.

Roberson, Q. M., \& Park, H. J. (2007). Examining the link between diversity and firm performance: The effects of diversity reputation and leader racial diversity. Group \& Organization Management, 32, 548-568. Available at: https://doi.org/10.1177/1059601106291124.

Roberts, R. W. (1992). Determinants of corporate social responsibility disclosure: An application of stakeholder theory. Accounting, Organizations and Society, 17(6), 595-612. Available at: https://doi.org/10.1016/0361-3682(92)90015$\mathrm{k}$.

Ross, S. A., Westerfield, R. W., \& Jaffe, J. (1996). Corporate finance, editorial Irwin (4th ed.). USA: International Student Edition.

Toluwa, O., Okun, O. O., \& Ikhenade, A. F. O. (2016). Determinants of environmental disclosure. International Journal of Advanced Academic Research Social \& Management Sciences, 2(8), 2488-9849.

Van Der Laan, S. (2010). The role of theory in explaining motivation for corporate social disclosures: Voluntary disclosures vs solicited disclosures. The Australasian Accounting Business \& Finance Journal, 3(4), 15- 29.

Wachira, M. (2017). Determinants of corporate social disclosures in Kenya: A longitudinal study of firms listed on the Nairobi securities exchange. European Scientific Journal, 13(11), 112-132. Available at: https://doi.org/10.19044/esj.2017.v13n11p112.

Waris, A., \& Muhammed, R. (2013). Factors influencing corporate social and environmental disclosure (Csed) practices in the developing countries: An institutional theoretical perspective. International Journal of Asian Social Science, 3(3), 590-609.

Wu, Jia - Liu, Linxiao. - Sulkowski, \& Adam. (2010). Environmental disclosure, firm performance, and firm characteristics: An analysis of S\&P 100 firms. Journal of Academy of Business and Economics, 10(4), 73-83.

Yakhou, M., \& Dorweiler, V. P. (2004). Environmental accounting: An essential component of business strategy. Business Policy and The Environment, 13(2), 65-77. Available at: https://doi.org/10.1002/bse.395. 